\title{
Gaucher Disease in the Neonate: A Distinct Gaucher Phenotype Is Analogous to a Mouse Model Created by Targeted Disruption of the Glucocerebrosidase Gene
}

\author{
ELLEN SIDRANSKY, DAVID M. SHERER, AND EDWARD I. GINNS \\ Section on Molecular Neurogenetics, Clinical Neuroscience Branch. National Institute of Mental Health, \\ Bethesda, Maryland 20892 /E.S., E.I.G.J and Department of Obstetrics and Gynecology. Division of Maternal-
} Fetal Medicine. Strong Memorial Hospital, Rochester, New' York 14642

\begin{abstract}
A group of neonates with Gaucher disease with a particularly devastating clinical course is described. The phenotype of these infants is analogous to that of a Gaucher mouse, which was created by targeted disruption of the mouse glucocerebroside gene. Similar to the homozygous mutant mice with glucocerebrosidase deficiency, these infants present at or shortly after birth, have rapidly progressing fulminant disease, and many have associated ichthyotic skin and/or hydrops fetalis. This transgenetic mouse model of Gaucher disease has helped us to appreciate a distinct Gaucher phenotype. Potentially, as this technology is applied to create other animal models of metabolic diseases, it may enable the recognition of other, as yet unappreciated presentations of inherited disorders. (Pediatr Res 32: 494-498, 1992)
\end{abstract}

A group of neonates having a uniquely devastating course as a consequence of Gaucher disease is described. The association of this phenotype with Gaucher disease was emphasized after observation of the phenotype of a glucocerebrosidase-deficient strain of transgenic mice created by targeted disruption of the mouse glucocerebrosidase gene.

Gaucher disease, the inherited deficiency of the lysosomal enzyme glucocerebrosidase (EC 3.2.1.45, $\beta$-D-glucosyl- $N$-acylsphingosine glucohydrolase) presents with diverse clinical manifestations $(1,2)$. To better understand the pathogenesis of this disease, a mouse model of glucocerebrosidase deficiency recently was generated by targeted disruption of the mouse gene $(3,4)$. This mouse line carries a null allele created by disrupting the presumptive active site of the glucocerebrosidase gene (2). The glucocerebrosidase activity in homozygous mutant mice was less than $4 \%$ of control, and the mice display a particularly devastating phenotype that is autosomal recessively inherited (4). Over 100 of these affected newborn animals have been studied. On electron microscopy, they demonstrate lipid storage in macrophages in liver, spleen, bone marrow, and brain. The homozygous mutant mice are readily identified by their mothers and are ejected from the nest. Compared to their unaffected littermates, they are cyanotic, lethargic, and exhibit poor turgor (Fig. 1). Their skin shows abnormal prominent rugation, and light microscopic evaluation reveals hyperkeratosis (Fig. $2 A$ and $B$ ). These mice have weak, irregular respirations, do not feed, and all die

Received for rapid publication June 10, 1992; accepted July 8, 1992.

Correspondence and reprint requests: Ellen Sidransky. M.D. Clinical Neuroscience Branch, National Institute of Mental Health, Building 10, Room 3N256, 9000 Rockville Pike. Bethesda, MD 20892. within $24 \mathrm{~h}$ of birth. With the observation of this striking mouse phenotype, we reviewed cases of Gaucher disease at our institutions and in the literature and have identified a subset of neonates diagnosed with severe type 2 Gaucher disease paralleling the clinical course observed in the glucocerebrosidase-deficient mouse.

\section{CASE REPORT I}

This infant was born at term by elective cesarean section to a 37-y-old gravida 2 para 1 Greek mother who had previously delivered a stillborn infant with unknown congenital malformations. On routine physical examination, he was found to have hepatosplenomegaly and was admitted to the neonatal intensive care unit for further investigation. At a few days of life, he developed hypertonia, hyperreflexia, and hyperextension of the neck (Fig. 3). His neurologic status progressively deteriorated; he demonstrated poor suck and swallow reflexes. Death occurred at $2 \mathrm{mo}$ of age. His $\beta$-glucosidase level was $0.81 \mathrm{nmol} / \mathrm{mg}$ protein/ h. On Western analysis of fibroblast extracts, no glucocerebrosidase protein was detected.

\section{CASE REPORT 2}

A 1935 -g male infant was born by cesarean section at 34 wk gestation to a 22 -y-old gravida 2 para 1 black mother. The early

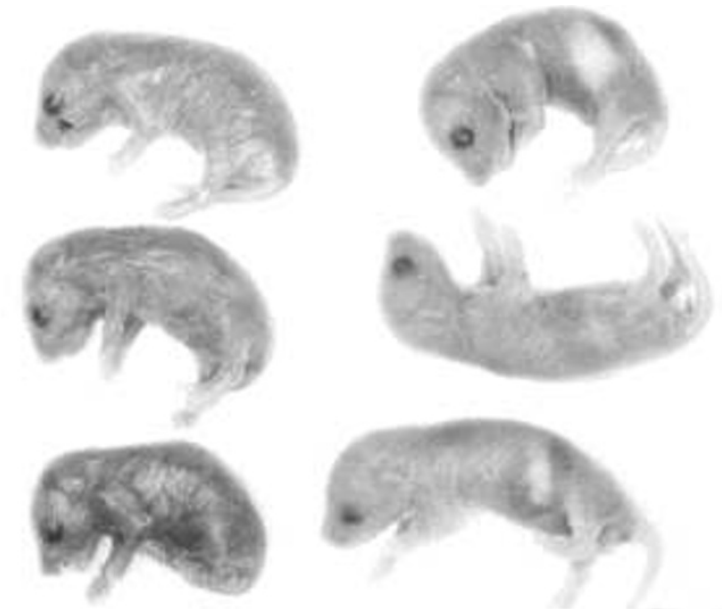

Fig. 1. Normal and homozygous mutant newborn mice. The six animals shown are littermates. The three affected mice (lefi) are cyanotic. smaller, and have absent spontaneous movements and rugated skin. The normal littermates ( $r i g h t$ ) are more active, demonstrate milk in their stomachs, and have good color and respirations. 

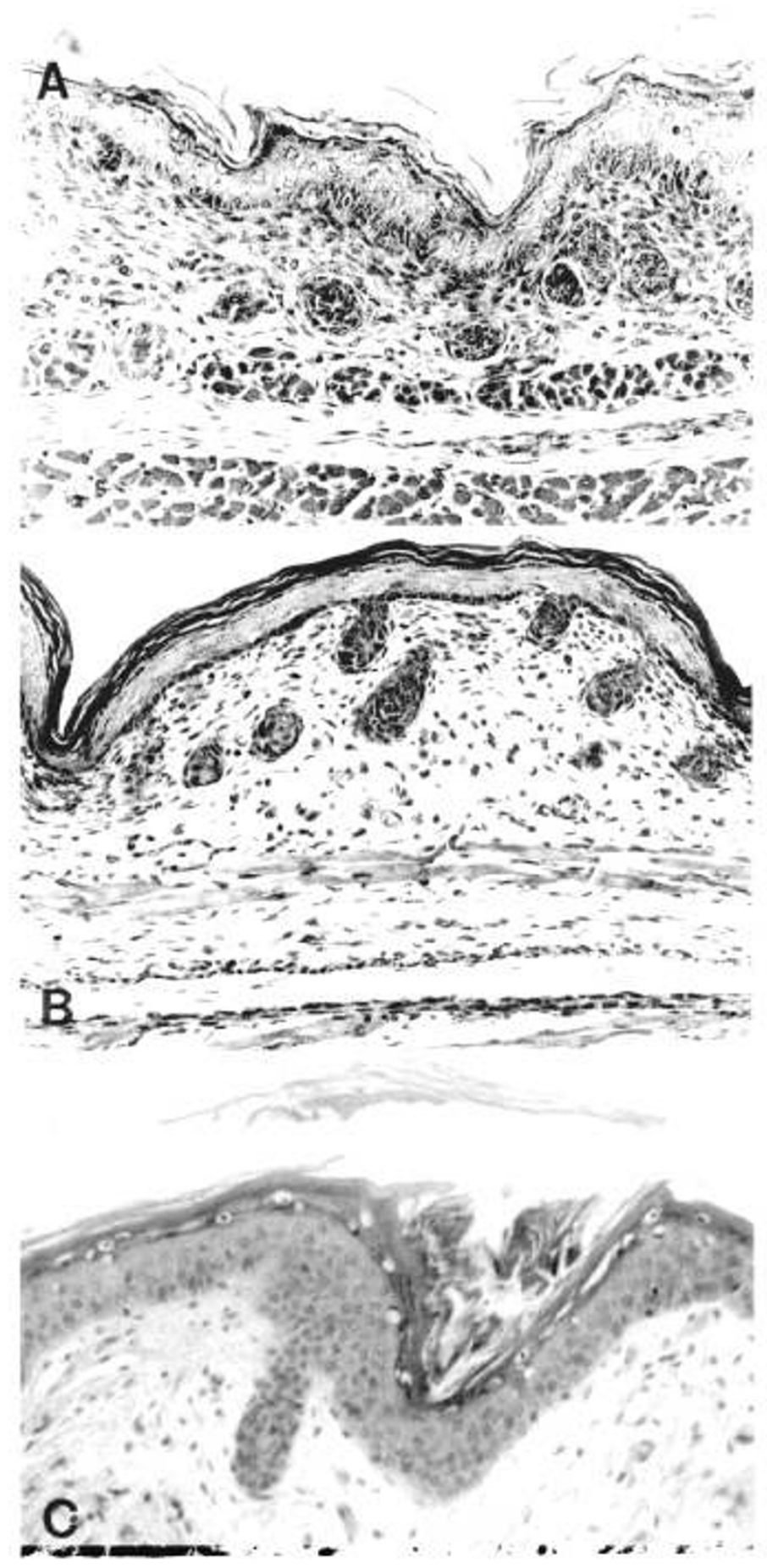

Fig. 2. Histologic appearance of skin (20X power, hematoxylin and cosin stain). $A$, Skin from a normal newborn mouse: $B$, skin from a homozygous mutant mouse (littermate of $A$ ); and $C$, skin from an infant with Gaucher disease and a collodion baby phenotype (case report 2).

portion of her pregnancy and sonograms at 14 and 22 wk were normal. However, 2 wk before delivery her uterus was noted to be large for dates, and a sonographic examination revealed massive polyhydramnios, absent fetal movements, thickened skin, and fetal facial features with a flattened nose, proptosis, and a continuously open mouth. The baby was born, with Apgar scores of 2, 2, and 2 at 1,5 , and $10 \mathrm{~min}$, respectively, and did not breathe spontaneously. He was noted to have stiff, thick, shiny collodion skin, flexed extremities, and open eyes and mouth (Fig. 4). Skin biopsy revealed lamellar exfoliative ichthyosis with normal epidermis and dermis but a thickened overly-

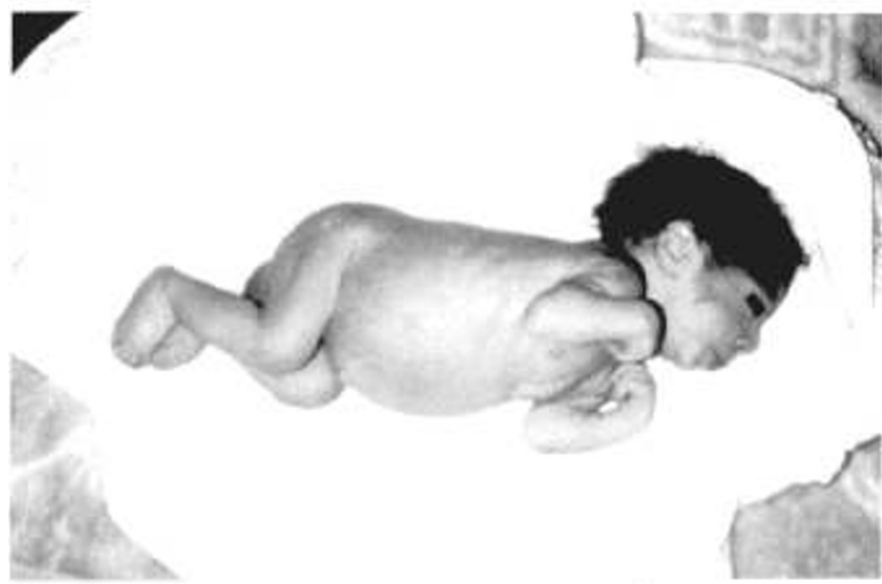

Fig. 3. Clinical photograph. Infant with Gaucher disease (case report 1) diagnosed in the newborn period with hepatosplenomegaly and neurologic disease.

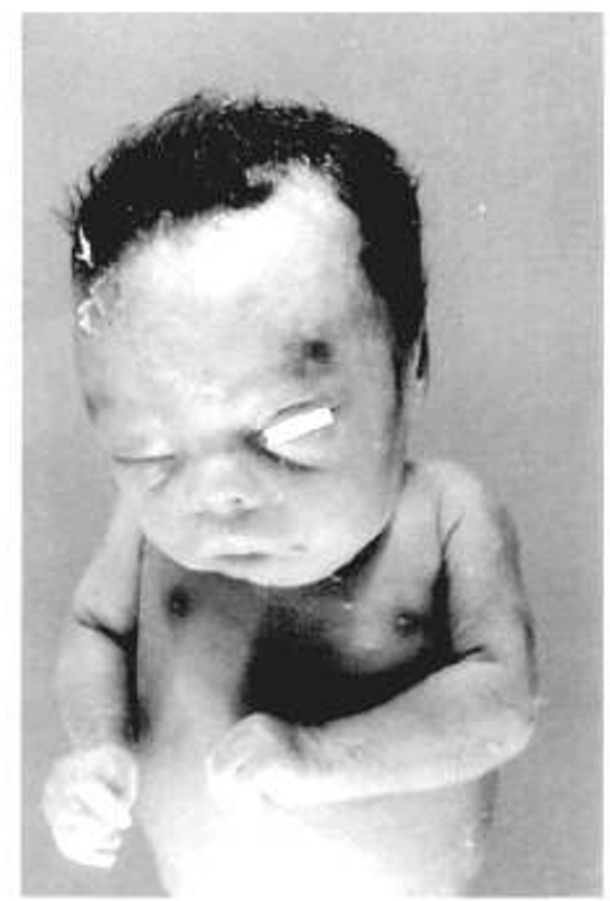

Fig. 4. Clinical photograph. Infant with Gaucher disease and congenital ichthyosis with restrictive dermopathy (case report 2).

ing keratin layer and follicular plugging with keratin (Fig. 2C). Mechanical ventilation was continued for $7 \mathrm{~d}$, but the infant had no spontaneous movements or respiratory effort. He also had absent auditory evoked potentials and an abnormal EEG with low-amplitude voltage. Life support was discontinued with parental consent and death immediately followed. On postmortem examination, large macrophages with lipid storage (Gaucher cells) were found in the spleen, liver, thymus, lymph nodes, adrenals, bone marrow, and throughout the CNS (5).

\section{REVIEW OF LITERATURE}

Examination of the literature (5-15) identified a group of 15 additional patients from 11 unrelated families in which Gaucher disease was eventually diagnosed because of symptoms presenting during the neonatal period (Table 1). In each of the cases, death ensued within days or months. There was no sex or ethnic predilection for this phenotype. Some of these infants were born at term and others were delivered at 32-36 wk gestation. 
Table 1. Gaucher patients presenting in neonatal period

\begin{tabular}{|c|c|c|c|c|c|c|c|c|}
\hline $\begin{array}{l}\text { Patient } \\
\text { no. }\end{array}$ & $\begin{array}{c}\text { Associated } \\
\text { diagnosis }\end{array}$ & $\begin{array}{l}\text { Year/ } \\
\text { reference }\end{array}$ & $\begin{array}{l}\text { Ethnic } \\
\text { origin }\end{array}$ & Sex & Gestation & Onset & $\begin{array}{l}\text { Age at } \\
\text { death }\end{array}$ & Miscellaneous \\
\hline 1 & Ichthyosis & $1988 / 6$ & Lebanese & $\mathbf{M}$ & $38 w k$ & Birth & 3 mo & $\begin{array}{l}\text { Ichthyotic skin, apathy, } \\
\text { hepatosplenomegaly, } \\
\text { respiratory death }\end{array}$ \\
\hline 2 & $\begin{array}{l}\text { Collodion } \\
\text { baby }\end{array}$ & $1988 / 6$ & $\begin{array}{l}\text { Lebanese } \\
\text { sibling of } \\
\text { case } 1\end{array}$ & $\mathbf{M}$ & $40 w k$ & Birth & $11 \mathrm{~d}$ & $\begin{array}{l}\text { Collodion skin, hepato- } \\
\text { splenomegaly, apathy, } \\
\text { convulsions }\end{array}$ \\
\hline 3 & $\begin{array}{l}\text { Collodion } \\
\text { baby }\end{array}$ & $1990 / 7$ & Australian & & $32 \mathrm{wk}$ & Birth & $3 \mathrm{wk}$ & $\begin{array}{l}\text { Mild collodion baby phe- } \\
\text { notype, hepatospleno- } \\
\text { megaly, thrombocyto- } \\
\text { penia, apnea }\end{array}$ \\
\hline 4 & $\begin{array}{l}\text { Collodion } \\
\text { baby }\end{array}$ & $\begin{array}{l}\text { Present } \\
\text { report } \\
\text { and } / 5\end{array}$ & Black & $\mathbf{M}$ & $34 w k$ & $\begin{array}{l}\text { Recognized } \\
\text { prenatally }\end{array}$ & $7 d$ & $\begin{array}{l}\text { Collodion skin, absent } \\
\text { movement, no sponta- } \\
\text { neous respirations }\end{array}$ \\
\hline 5 & Ichthyosis & $1984 / 8$ & & $\mathbf{M}$ & Term & Birth & $13 w k$ & $\begin{array}{l}\text { Jittery from birth, con- } \\
\text { genital lamellar ich- } \\
\text { thyosis, trismis, hepa- } \\
\text { tosplenomegaly, hyper- } \\
\text { extension of neck, dys- } \\
\text { conjugate gaze }\end{array}$ \\
\hline 6 & Ichthyosis & $1962 / 9$ & & $\mathbf{M}$ & Term & Birth & $3 \mathrm{mo}$ & $\begin{array}{l}\text { Cellophane skin, pete- } \\
\text { chial rash, hepatosple- } \\
\text { nomegaly, opisthonus, } \\
\text { respiratory death }\end{array}$ \\
\hline 7 & $\begin{array}{l}\text { Ichthyosis } \\
\text { and hy- } \\
\text { drops }\end{array}$ & $1954 / 10$ & German & F & & Birth & $16 \mathrm{~h}$ & $\begin{array}{l}\text { Congenital ichthyosis, } \\
\text { hepatosplenomegaly, } \\
\text { apnea, erythroblastosis, } \\
\text { aortic calcification }\end{array}$ \\
\hline 8 & Hydrops & $1954 / 10$ & $\begin{array}{l}\text { German sib- } \\
\text { ling of } \\
\text { case } 7\end{array}$ & $\mathrm{~F}$ & & Birth & $2 \mathrm{~h}$ & $\begin{array}{l}\text { Congenital hydrops, hep- } \\
\text { atosplenomegaly }\end{array}$ \\
\hline 9 & Hydrops & $1984 / 11$ & Black & $\mathbf{M}$ & $38 \mathrm{wk}$ & Birth & $71 / 2 \mathrm{~h}$ & $\begin{array}{l}\text { Generalized edema, hy- } \\
\text { drops fetalis, wide- } \\
\text { spread petechie, } \\
\text { marked hepatospleno- } \\
\text { megaly }\end{array}$ \\
\hline 10 & Hydrops & $1973 / 12$ & Caucasian & & 34 wk & Stillborn & & $\begin{array}{l}\text { Macrated stillborn, gen- } \\
\text { eralized edema }\end{array}$ \\
\hline 11 & Hydrops & $1973 / 12$ & $\begin{array}{l}\text { Caucasian } \\
\text { sibling of } \\
\text { case } 10\end{array}$ & $\mathbf{M}$ & 36 wk & Birth & $20 \mathrm{~min}$ & $\begin{array}{l}\text { Hepatosplenomegaly, } \\
\text { edema, hydrops fetalis, } \\
\text { pleural effusions, and } \\
\text { ascites }\end{array}$ \\
\hline 12 & $\begin{array}{l}\text { Possible } \\
\text { hydrops }\end{array}$ & $1970 / 13$ & $\begin{array}{l}\text { Sephardic } \\
\text { Jewish }\end{array}$ & $\mathrm{F}$ & $32 w k$ & Birth & $48 \mathrm{~h}$ & $\begin{array}{c}\text { Edema, hepatospleno- } \\
\text { megaly, apnea, pur- } \\
\text { pura, ? hydrops, four } \\
\text { previous miscarriages }\end{array}$ \\
\hline 13 & & $1938 / 14$ & $\begin{array}{l}\text { Caucasian } \\
\text { American }\end{array}$ & $F$ & & l wk & $4.5 \mathrm{mo}$ & $\begin{array}{l}\text { Opisthotonus, neck rigid- } \\
\text { ity, strabismis, poor } \\
\text { feeding, hepatospleno- } \\
\text { megaly }\end{array}$ \\
\hline 14 & & $1974 / 15$ & Spanish & $\mathrm{F}$ & $32 \mathrm{wk}$ & $\begin{array}{l}\text { Less than } 2 \\
\quad \text { wk }\end{array}$ & $3 \mathrm{mo}$ & $\begin{array}{l}\text { Generalized spasticity, } \\
\text { hepatosplenomegaly, } \\
\text { apnea, poor feeding }\end{array}$ \\
\hline 15 & & $1974 / 15$ & $\begin{array}{l}\text { Spanish sib- } \\
\text { ling of } \\
\text { case } 14\end{array}$ & $\mathbf{M}$ & & Stillborn & & \\
\hline 16 & & $1974 / 15$ & $\begin{array}{l}\text { Spanish sib- } \\
\text { ling of } \\
\text { case } 14\end{array}$ & $\mathrm{~F}$ & & & $45 \mathrm{~d}$ & \\
\hline 17 & & $\begin{array}{l}\text { Present } \\
\text { report }\end{array}$ & Greek & $\mathbf{M}$ & Term & Birth & $2 \mathrm{mo}$ & $\begin{array}{l}\text { Hepatosplenomegaly, hy- } \\
\text { pertonia, hyperreflexia, } \\
\text { hyperextension of neck }\end{array}$ \\
\hline 18 & & $\begin{array}{l}\text { Present } \\
\text { report }\end{array}$ & $\begin{array}{l}\text { Greek sib- } \\
\text { ling of } \\
\text { case } 17\end{array}$ & & & Stillborn & & $\begin{array}{l}\text { Unknown congenital } \\
\text { malformations }\end{array}$ \\
\hline
\end{tabular}


Noteworthy were associated dermatologic manifestations. In seven of the case reports, the infants were described as either "collodion babies" or as having congenital ichthyosis or "cellophane-like" skin (5-10). In the earlier reports, this finding was not emphasized but was described as an incidental observation. However, more recently Lui et al. (6) and Lipson et al. (7) reported the association and commented that the ichthyosis might be related to abnormal lipid composition of the skin or, alternatively, that the hyperkeratosis and glucocerebrosidase deficiency may be the result of contiguous gene disorders. Interestingly, there was no mention of Gaucher disease in large reviews of collodion babies $(16,17)$.

Another observation is the association of Gaucher disease and hydrops fetalis. Six infants in four unrelated families were described with Coombs negative hydrops and Gaucher disease with CNS involvement (10-13). These patients all succumbed within the first $24 \mathrm{~h}$ of life. In one family (10), two infants were described who most probably had nonimmune erythroblastosis and Gaucher disease. The second of these children also had shiny, reflective, thin "cellophane paper-like" skin with hemorrhagic rugation.

\section{DISCUSSION}

Type 2 or acute neuronopathic Gaucher disease is generally thought to be fairly stereotypic in its presentation $(1,9,13)$. The child is usually born at term after an uneventful pregnancy and appears normal at birth. Several months pass before the first diagnostic signs appear, which may manifest as failure to thrive hepatosplenomegaly, or difficulty in feeding or swallowing. Once the neurologic symptoms begin they progress rapidly, and there is loss of developmental milestones. Classically, the affected infants develop hyperextension of the neck, strabismus, trismus, and hypertonia with hyperreflexia. Death generally occurs between age 9 and 18 mo $(1,9,13)$. The infants with type 2 Gaucher disease described in this report clearly had a different and more severe phenotype. In the subset of patients described here, signs and symptoms presented prenatally or at birth, and death frequently ensued within hours to days, or at the most 2 3 mo. In these infants there was an association with congenital ichthyosis and/or hydrops fetalis.

Although the initial cases of perinatal Gaucher disease were reported more than 50 y ago (13), this more severe presentation has not been recognized as a distinct entity. Most of the cases were only identified serendipidously, often after other siblings had died undiagnosed. Thus, it is important that physicians, particularly neonatologists and dermatologists, recognize these cases to appreciate the full spectrum of manifestations of Gaucher disease.

The use of transgenic technology to create animal models of human disease is still in its infancy (18). There is the possibility that mutations introduced into an animal gene could result in either a phenotype that is not analogous to that seen in the human disorder (19) or a lethal phenotype. The targeted disruption of the mouse glucocerebrosidase gene to produce a null allele has resulted in an homozygous mouse who was affected, in this instance severely, with Gaucher disease. We now have examined, by Southern analysis, more than 100 homozygousmutant mice, all of whom died in the first $24 \mathrm{~h}$ of life. Specific clinical manifestations of this mouse, particularly its ichthyotic skin and early demise, have aided us in recognizing and beginning to emphasize a distinct human phenotype of Gaucher disease. The generation of other, less severely affected mouse lines should provide insight into other aspects of the human disease.

The association of Gaucher disease with congenital ichthyosis in both the human and the mouse is particularly noteworthy. The skin abnormality observed in the Gaucher mouse generated by targeted disruption of the glucocerebrosidase gene suggests that the association in the human is not due to contiguous genes
$(6,7)$. The enzyme deficiency with resultant abnormal glucocerebroside degradation appears directly responsible for the abnormal skin of these infants. Glucosylceramide and ceramide are components of the intercellular bilayers in the stratum corneum of normal skin $(20,21)$. Recently, sphingolipids have been demonstrated to play an important role in skin permeability barrier homeostasis (22). The absence of glucocerebrosidase may consequently affect functional skin integrity. Histologically, the thickened overlying keratin layer was found in skin of both the homozygous mutant mice and an affected human neonate. Thus, Gaucher disease should be considered in the differential diagnosis of the "collodion baby" or congenital ichthyotic skin phenotype. Early diagnosis of type 2 Gaucher disease is essential for genetic counseling and assigning prognosis.

Although the association of Gaucher disease and hydrops fetalis has been reported, the pathophysiology of the phenomena still remains obscure. Fetal pathology of Gaucher disease has been studied $(23,24)$, and there is documentation of advanced pathologic alterations in fetal tissues. There was an increase in perinatal deaths and spontaneous abortions among the families reviewed here, but Gaucher disease often was only recognized when a second child was affected. The observation of this fetal loss associated with Gaucher disease has been reported in the past (25). Further systematic study of the incidence of perinatal deaths among Gaucher families should prove helpful. Perhaps Gaucher disease has been underdiagnosed in the neonatal period.

Gaucher disease exhibits a large degree of phenotypic heterogeneity, and it is not surprising that subsets of type 2 patients exist with different clinical courses. Among type 2 patients studied, multiple genotypes have been identified and many individuals have alleles that have not yet been defined $(2,26-28)$. However, the finding that the infant described in case report 1 was similar to the glucocerebrosidase-deficient mouse in that it had almost no enzyme activity and no detectable enzyme on Western analysis is unusual. Generally, no unique DNA mutation or particular range of residual glucocerebrosidase activity (29) is specifically found in type 2 patients. A total absence of cross-reactive material on Western analysis is not usually seen in Gaucher patients (2), although one other case has been reported (30). Thus, even type 2 patients may prove less homogeneous than previously thought.

The glucocerebrosidase-deficient mouse is the first animal model of an inborn error of metabolism with an appropriate phenotype created by gene targeting. This initial transgenic model of Gaucher disease having a null allele has provided us with valuable insight into the human disease. It may also aid in the investigation of the role of specific lipids in skin. Potentially, as this transgenic technology is applied to create other animal models of metabolic diseases, it may enable us to recognize other, as yet unappreciated presentations of inherited disorders.

\section{REFERENCES}

1. Barranger JA, Ginns El 1989 Glucosylceramide lipidoses: Gaucher disease. In: Metabolic Basis of Inherited Disease. McGraw-Hill, New York, pp 1677 1698

2. Martin BM, Sidransky E, Ginns EI 1989 Gaucher disease: advances and challenges. Adv Pediatr 36:277-306

3. Tybulewicz V, Tremblay ML, LaMarca ME, Stubblefield BK, Winfield S, Zablocka B, Sidransky E, Martin BM, Westphal H, Mulligan RC, Ginns EI 1991 Generation of chimeric mice with glucocerebrosidase gene mutations introduced by targeted homologous recombination in embryonic stem cells to produce a mouse model of Gaucher disease. Am J Hum Genet 49:44!

4. Tybulewicz V, Tremblay ML, LaMarca ME, Willemsen R, Stubblefield BK, Winfield S, Zablocka B, Sidransky E, Martin BM, Huang SP, Mintzer KA, Westphal H. Mulligan RC. Ginns EI 1992 Animal model of Gaucher's disease from targeted disruption of the mouse glucocerebrosidase gene. Nature 357:407-410

5. Sherer DM, Metlay L, Sinkin RA, Mongeon C, Lee RE, Woods JR 1992 Congenital ichthyosis with restrictive dermopathy and Gaucher's disease: a new syndrome with associated prenatal diagnostic and pathology findings. Obstet Gynecol (in press)

6. Liu K, Commens C, Choong R, Jaworski R 1988 Collodion babies with Gaucher's disease. Arch Dis Child 63:854-856 
7. Lipson AH, Rogers M, Berry A 1991 Collodion babies with Gaucher's disease: a further case. Arch Dis Child 66:667

8. Lacey DJ. Terplan K 1984 Correlating auditory evoked and brainstem histologic abnormalities in infantile Gaucher's disease. Neurology 34:539-54

9. Banker BQ, Miller JQ. Crocker AC 1962 The cerebral pathology of infantile Gaucher disease. In: Aronson SM, Volk BW (eds) Cerebral Sphingolipidoses. Academic Press, New York, pp 73-99

10. Girgensohn H, Kellner H, Südhof H 1954 Angeborener morbus Gaucher bei erythroblastose und Gefässverkalkung. Klin Wochenschr 32:57-64

11. Sun CC. Panny S, Combs J, Gutberlett R 1984 Hydrops fetalis associated with Gaucher disease. Pathol Res Pract 179:101-104

12. Ginsburg SJ, Groll M 1973 Hydrops fetalis due to infantile Gaucher's disease. J Pediatr 82:1046-1048

13. Drukker A, Sacks MI, Path MC, Gatt S 1970 The infantile form of Gaucher's disease in an infant of Jewish Sephardi origin. Pediatrics 45:1017-1023

14. Aballi AJ, Kato K 1938 Gaucher disease in early infancy: review of literature and report of case with neurological symptoms. J Pediatr 13:364-380

15. Gonzalez-Sastie F, Pompols T, Sabater J 1974 Infantile Gaucher's disease: a biochemical study. Neurology 24:162-197

16. Larrégue M, Bressieux JM, Fournet JP 1978 Collodion baby. Mod Probl Paediatr 20:40-49

17. Larrégue M, Ottavy N, Bressieux JM, Lorette J 1986 Bébé collodion: trentedeux nouvelles observations. J Dermatol Venereol 113:773-785

18. Williams D 1990 Embryonic stems cells as targets for gene transfer: a new approach to molecular manipulation of the murine hematopoietic system. Bone Marrow Transplant 5:141-144

19. Kuehr MR, Bradley A, Robertson EJ, Evans MJ 1989 A potential animal model for Lesch-Nyhan syndrome through introduction of HPRT mutations into mice. Nature 326:295-298

20. Elias P 1981 Epidermal lipids, membranes and keratinization. Int J Dermatol
20:1-18

21. Williams ML 1986 A new look at the ichthyoses disorders of lipid metabolism. Pediatr Dermatol 3:476-497

22. Holleran WM, Mao-Qiang M. Gao WN, Menon GK, Elias PM, Feinfold KR 1991 Sphingolipids are required for mammalian epidermal barrier function: inhibition of sphingolipid synthesis delays barrier recovery after acute perturbation. J Clin Invest 88:1338-1345

23. Schneider EL, Ellis WG, Brady RO, McCulloch JR, Epstein CJ 1972 Infantile (type II) Gaucher's disease: in utero diagnosis and fetal pathology. J Pediatr 81:1134-1139

24. Kamoshita S, Odawara M. Yoshida M, Owada M. Kitagawa T 1976 Fetal pathology and ultrastructure of neuronopathic Gaucher's disease. In: Volk BW, Schneck L (ed) Current Trends in Sphingolipidoses and Allied Disorders. Plenum Press, New York, pp 63-75

25. Hsia DYY, Naylor J, Bigler JA 1962 The genetic mechanism of Gaucher's disease. In: Aronson SM, Volk BW (eds) Cerebral Sphingolipidoses. Academic Press, New York, pp 327-342

26. Sidransky E, Tsuji S, Martin BM, Stubblefield B, Ginns EI 1992 DNA mutation analysis of Gaucher patients. Am J Med Genet 42:331-336

27. Eyal N, Wilder S. Horowitz M 1990 Prevalent and rare mutations among Gaucher patients. Gene 96:277-283

28. Latham T, Theophilus BDM, Grabowski GA, Smith FI 1991 Heterogeneity of mutations in the acid $\beta$-glucosidase gene of Gaucher disease patients. DNA Cell Biol 10:15-21

29. Wenger DA, Olson GC 1981 Heterogeneity in Gaucher's disease. In: Callahan JW, Cowten JA (eds) Lysosomes and Lysosomal Storage Disorders. Raven Press. New York, pp 157-171

30. Fabbro D, Desnick RJ, Grabowski GA 1987 Gaucher disease: genetic heterogeneity within and among the subtypes detected by immunoblotting. Am J Hum Genet 40:15-31 